\title{
ANALISIS LAPORAN KEUANGAN SEBAGAI DASAR PENILAIAN TERHADAP KINERJA KEUANGAN PEMERINTAH DAERAH KOTA PALOPO
}

\section{ROSIDA TOSELONG, HAPID, ANTONG}

\begin{abstract}
ABSTRAK
Mardiasmo (2002 : 2) menjelaskan bahwa "dari sudut pandang ekonomi, sector public dapat dipahami sebagai suatu entitas yang aktifitasnya berhubungan dengan usaha untuk mnghasilkan barang dan pelayanan public dalam rangka memenuhi kebutuhan dan hak public”. Indra Bastian (2001 : 6) menjelaskan tentang pengertian Akuntansi Sektor Publik adalah "Mekanisme teknik dan analisis akuntansi yang diterapkan pada pengelolaan dana masyarakat di lrmbaga-lembaga tinggi Negara dan departemen-departemen di bawahnya, pemerintah daerah, BUMN, BUMD, LSM, dan yayasan social, maupun pada proyek-proyek kerjasama sector public dan swasta.

Penelitian ini bertujuan untuk mengetahui kinerja keuangan Pemerintah Kota Palopo dalam hal efektifitas dan efisiensi terhadap APBD tahun anggaran 20092011. Metode penelitian yang digunaka yaitu metode wawancara, dengan mengadakan wawancara langsung dengan sejumlah pegawai yang berhubungan dengan penelitian ini. metode Dokumentasi, dilakukan dengan jalan mengumpulkan dokumen-dokumen yang berhubungan dengan penelitian ini.

Berdasarkan hasil analisis data tersebut, dapat mengambarkan kemampuan pemerintah daerah dalam merealisasikan pendapatan asli daerah yang direncanakan dibandingkan dengan target yang ditetapkan berdasarkan potensi riil daerah (efektifitas).

Kesimpulanya bahwa hasil perhitungan untuk rasio efektifitas dan efisiensi Pendapatan Asli Daerah Kota Palopo, kinerja keuangan Pemerintah Kota Palopo dalam merealisasikan PAD yang direncanakan dibandingkan dengan Anggaran yang ditetapkan belum efektif karena rasio efektifnya belum mencapai 1 (satu) atau 100 persen.
\end{abstract}

Kata kunci: Laporan Keuangan Penilaian, Kinerja Keuangan, Pemerintah

\section{Pendahuluan}

\section{Latar Belakang}

Badai krisis yang terjadi di Indonesia pada tahun 1997 dan tumbangnya rezim orde baru merupakan titik awal perjalanan bangsa Indonesia dalam menjalani reformasi di berbagi bidang baik politik, ekonomi, social dan budaya dan lain-lain. Upaya pemerintah untuk melakukan perubahan diantaranya adalah mewujudkan tatakelola pemerintah yang baik (Good Govemance), perubahan pola pemerintah yang semula sentralistik menjadi desentralistik yang lebih demokratis setelah diperlakukanya otonomi daerah (UU No. 22 tahun 1999). Perubahan juga terjadi di lembaga legislative yaitu adanya amandemen terhadap UUD 1945.

Manajemen keuangan pemerintah merupakan salah satu kunci penentu keberhasilan pembangunan dan penyelenggaraan pemerintah dalam kerangka nationan and state building. Adanya manajemen keuangan pemerintah yang baik akan menjamin tercapainya tujuan pembangunan secara khusus dan tujuan berbangsa dan benegara secara umum. 
Dalam upaya perwujudan manajemen keuangan pemerintah yang baik, terdapat pula tuntutan yang semakin aksentuatif untuk mengkakomodasi, menginkorporasi, bahkan mengedepankan nilai-nilai good govemance. Beberapa nilai yang relevan dan urgen untuk diperjuangkan adalah antara lain transparansi, akuntabilitas, serta partisipasi masyarakat dalam proses pengelolaan keuangan dimaksud, disamping nilai-nilai efektifitas dan efisiensi.

Dengan adanya reformasi manajemen keuangan Negara telah direncanakan di Indonesia melalui satu paket undang-undang dibidang keuangan Negara.

Dengan lahirnya tiga paket UU dibidang pegelolaan keuangan Negara yaitu: UU No.17 tahun 2003 tentang "' keuangan Negara" UU No.1 tahun 2004, tentang "'perbendaharaan Negara" dan UU No.15 tahun 2004 tentang 'pemeriksaan dan pertanggung jawaban Negara" ketiga paket tersebut telah meletakkan dasar-dasar pengelolaan keuangan Negara menyangkut perencanaan, penganggaran, dan indepedensi pemeriksaan serta pembagian kewenangan administrative antar lembaga Negara sekaligus menjadi landasan hokum ( framework) pengelolaan keuangan Negara di Indonesia.

Lembaga pemerintah dalam menjalankanpemerintahanya memerlukan jasa akuntansi, baik analisis maupun untuk meningkatkan mutu pengawasan, pendidikan, dan pengelolaan keuangan untuk menghasilkan informasi yang akan digunakan. Akuntansi demikian dikenal dengan akuntansi pemerintahan. Akuntansi pemerintahan merupakan bidang akuntansi yang berkaitan dengan lembaga pemerintahan dan lembaga-lembaga tidak bertujuan mencari laba.

Berdasarkan pembahasan tersebut maka akuntansi pemerintahan dalam hal ini digunakan dalam suatu organisasi pemerintahan / lembaga yang tidak bertujuan untuk mencari laba, dan merupakan suatu bagian dari disiplin ilmu akuntansi sebagai bagian yang utuh. Sehubungan dengan hal tersebut pada dua tahun terakhir, opini badan pemeriksa keuangan RI atas pengelolaan keuangan daerah berdasarkan APBD Kota Palopo adalah Disclaimer, karenanya penulis tertarik memberi judul "Analisis Laporan Keuangan Sebagai Dasar Penelitian Terhadap Kinerja Keuangan Pemerintah Daerah Kota Palopo".

Masalah penelitian ini adalah bagaimana kinerja keuangan Pemerintah Kota Palopo dalam hal efektifitas dan efisiensi terhadap APBD tahun anggaran 2009-2011?. Tujuan penelitian ini adalah untuk mengetahui kinerja keuangan Pemerintah Kota Palopo dalam hal efektifitas dan efisiensi terhadap APBD tahun anggaran 20092011.

\section{Metode Penelitian}

Lokasi dan Waktu Penelitian

Adapun yang menjadi lokasi penelitian dalam penulisan ini adalah Kota Palopo tepatnya pada Dinas Pendapatan Pengelolaan Keuangan dan Aset Daerah (DPPKAD) Kota Palopo. Sedangkan waktu penelitian dimulai dari berlangsung selama dua bulan yaitu Bulan Mei sampai dengan Juni 2012.

Jenis dan Sumber Data

1. Data kualitatif

2. Data kuantitatif

Semua data yang digunakan adalah data Sekunder Time Series Tahun Anggaran 2009 s/d 2011 . 
Metode Pengumpulan Data

Metode pengumpulan data yang dilakukan adalah: (a) Observasi; Yaitu penelitian yang dilakukan dengan mengadakan pengamatan secara langsung pada Dinas Pendapatan Pengelolaan Keuangan dan Aset Daerah (DPPKAD) Kota Palopo. (b) Wawancara; Yaitu penelitian yang dilakukan dengan mengadakan wawancara langsung dengan sejumlah pegawai yang berhubungan dengan penelitian ini. (c) Dokumentasi; Adalah penelitian yang dilakukan dengan jalan mengumpulkan dokumen-dokumen yang berhubungan dengan penelitian ini.

\section{Hasil Penelitian Dan Pembahasan}

Gambaran Umum Kota Palopo

Sejarah singkat.

Kota palopo, dahulu disebut kota administrativ (kotik) palopo, merupakan ibu kota kabupaten luwu yang di bentuk berdasarkan peraturan pemerintah (PP) Nomor Tahun42 Tahun 1986

Seiring dengan perkembangan zaman, tatakala gaung reformasi bergulir dan melahirkan UU No. 22 tahun 1999 dan PP 129 tahun 2000. Telah membuka peluang bagi kota Administrasi di seluruh Indonesia yang telah memenuhi sejumlah persyaratan untuk dapat di tingkatkan statusnya menjadi sebuah daerah otonomi.

Ide peningkatan status kotip palopo menjadi daerah otonomi bergulir melalui aspirasi masyarakat yang menginginkan peningkatan status kala itu, yang di tandai da=endan lahirnya beberapa dukungan peningkatan status kotmip palopo menjadi daerah otonomi kotab palopo dari beberapa unsure kelembagaan penguat seperti seperti surat Bupati Luwu No. 135/09/TAPEM Tanggal januari 2001, tentang usul peningkatan status kotip palopo menjadi kota palopo :keputusan DPRD kabupaten luwu No. 55 tahun 2000 tanggal 7 september 2000 tentang persetujuan pemekaran/peningkatan status kotip palopo menjadi kota otonomi.

Akhirnya setelah pemerintah pusat melalui depdagri meninjau kelengkapan administrasi serta melihat sisi potensi, kondisi wilayah dan letak giografis kotip palopo yang berada pada jalur trans Sulawesi dan sebagai pusat pelayanan jasa perdagangan terhadap beberapa kabupaten sekitar,meliputi kabupaten luwu, luwu utara, tana toraja dan kabupaten wajo dan di dukung sebagai pusat pengembangan pendididkan di kawasan utara Sulawesi selatan.

Tanggal 2 juli 2002 , merupakan salah satu tonggak sejarah perjuangan pembangunan kota palopo, dengan di tanda tanganinya prasasti pengakuan atas daerah otonom kota palo[po oleh bapak manteri dalam negeri republic Indonesia, berdasarkan undang-undang No. 11 tahun 2002 tentang pembentukan daerah otonom.dengan bentuk dan model pemerintahan serta letak wilayah geografis tersendiri. Angaran Pendapatan dan Belanja Daerah Kota Palopo Tahun angaran tahun 2009-2011

Pada umumnya APBD suatu daerah di dominasi oleh sumbangan pemerintahan pusat dan sumbangan lain-lain, yang di atur dengan peraturan perundang-undangan, yaitu sekitar 75\% dari trotal penerimaan daerah. 
Anggaran pendapatan dan belanja daerah merupakan proses penggaran daerah dimana secra konsepsual terdiri dari formulasi kebijakan anggaran (Budget policy formulation) dan perencanaan (Budget operational planning).

Dalam UU Nomor 25 tahun 2004 tentang system perencanaan pembangunan nasional pada dasranya mengamanatkan bahwa perencanaan pembangunan daerah adalah satu kesatuan dalam sistem perencanaan nasional dengan tujuan untuk menjamin adanya keterkaitan dan konsistensi antara perencanaan ,penganggaran, pelaksanaan serta pengendalian dan pengawasan.

Penyusunan RKA-SKPD merupakan bentuk pengalokasian sumber daya keuangan pemerintah daerah. Secara umum kebijakan pengalolaan anggaran lima tahun kedepan di laksanakan berdasarkan PP nomor 58 tahun 2005 tentang pengelolaan keuangan daerah yang selanjutnya di jabarkan melalui permendagri 13 tahun 2006 dan apabila terjadi perubahan pada peraturan pemerintah tersebut kearah pengelolaan keuangan daerah yang lebih baik maka akan di lakukan penyesuaian.

APBD Kota Palopo yang di gunakan untuk pembiayaan kegiatan pemerintahan,kemasyrakatan dan pembangunan daerah terus meningkat dari tahun ke tahun.siklus perkembangan APBD sejak tahun 2009 sampai dengan 2011 yang meliputi realisasi anggaran pendapatan dan belanja rutin (Belanja Aparatur Daerah) dan belanja pembagunan (Belanja Pelayanan Publik) dapat di lihat dari table di bawah ini:

Table 4.4 Realisasi Pendapatan, Belanja Rutin, dan Belanja Pembangunan Kota Palopo Tahun Anggaran 2009-2011

\begin{tabular}{|c|c|c|c|c|}
\hline \multirow[t]{2}{*}{ No } & \multirow[t]{2}{*}{ Tahun } & \multicolumn{3}{|l|}{ realisasi } \\
\hline & & Pendapatan & Belanja rutin & $\begin{array}{l}\text { Belanja } \\
\text { pembangunan }\end{array}$ \\
\hline 1 & 2009 & 371.691 .322 .536 .00 & 253.767 .598 .014 .55 & 134.783 .044 .471 .00 \\
\hline 2 & 2010 & 380.228 .832 .310 .07 & 309.257 .102 .941 .00 & 94.769 .455 .183 .00 \\
\hline 3 & 2011 & 463.461.308.309.92 & 383.283.159.778.54 & 115.120 .298 .258 .00 \\
\hline \multicolumn{2}{|c|}{ total } & 1.215 .381 .463 .155 .99 & $946,307,860,734.09$ & $344,672,797,912.00$ \\
\hline
\end{tabular}

Sumber: Data DPPKAD Kota Palopo, 2011

Dari data tersebut di atas, menggambarkan perkembangan APBD Kota Palopo dari TA. 20092011 mengalami kenaikan. Realisasi APBD pada tahun 2010 mengalami kenaikan sebesar 3.06 $\%$, sedangkan pada tahun 2011 mengalami kenaikan sebesar $18.47 \%$. Hal ini disebabkan karena jumlah pendapatan yang kian bertambah dimana realisasi pendapatan semakin menigkat seiring dengan bertambahnya jumlah angaran yang di tetapkan.

Perhitungan dan Analisis Rasio Kinerja Keuangan Pemerintah Kota Palopo

Pendapatan Asli Daerah (PAD) merupakan pendapatan yang diperoleh daerah dari sumber-sumber dalam wilayahnya sendiri yang dipungut berdasarkan peraturan daerah sesuai dengan peraturan perundang-undangan yang berlaku.

Pengelolaan Pendapatan Asli Daerah (PAD) ini ditangani langsung oleh pemerintah daerah, melalui kebijakan yang ditempuh untuk mencapai target. Pada daerah otonom diharapkan pendapatan Asli Daerah (PAD) dapat menutupi kebutuhan sendiri. Tapi dalam 
kenyataanya pendapatan Asli Daerah (PAD) belum mampu/belum mencukupi untuk membiayai kebutuhan rutin apalagi untuk biaya pembangunan.

Perkembangan ekonomi suatu daerah mengindikasikan perekonomian masyarakat menuju ke arah yang lebih baik dan juga dapat menyebabkan perubahan yang besar terhadap peningkatan anggaran dan realisasi Pendapatan Asli Daerah (PAD) Kota Palopo.

\section{Rasio Efektifitas}

Rasio efektifitas adalah menggambarkan kemampuan pemerintah kota palopo dalam merealisasikan PAD yang direncanakan dibandingkan dengan anggaran yang ditetapkan berdasarkan

Tabel 4.5 Target / Anggaran dan Realisasi PAD

Kota Palopo TA 2009-2010

\begin{tabular}{|l|l|l|l|}
\hline Tahun & $\begin{array}{l}\text { Targed PAD } \\
(\mathrm{Rp})\end{array}$ & Realisasi PAD (Rp) & $\begin{array}{l}\text { Rasio } \\
\text { Efektifitas \% }\end{array}$ \\
\hline 2009 & 23.216 .090 .835 .00 & 21.550 .761 .903 .30 & 92.83 \\
\hline 2010 & 32.270 .012 .633 .00 & 28.219 .019 .905 .66 & 87.45 \\
\hline 2011 & 37.953 .581 .200 .00 & 35.703 .421 .516 .00 & 94.07 \\
\hline
\end{tabular}

Sumber : DPPKAD Kota Palopo

Rasio efektifitas pemerintah kota palopo:

Tahun $2009: \underline{21.550 .761 .903 .30} \times 100=92.83 \%$

23.216.090.835

Berdasarkan hasil analisis data tersebut, dapat mengambarkan kemampuan pemerintah daerah dalam merealisasikan pendapatan asli daerah yang direncanakan dibandingkan dengan target yang ditetapkan berdasarkan potensi riil daerah

(efektifitas).

\section{Rasio efisiensi}

Untuk mendapatkan hasil yang lebih optimal, rasio efektifitas pendapatan asli daerah perlu disandingkan dengan rasio efisiensi pendapatan asli daerah yang dicapai pemerintah daerah.

Rasio efisiensi adalah membandingkan antara besarnya biaya yang dikeluarkan untuk memperoleh pendapatan dibandingkan dengan realisasi pendapatan yang diterima.

Rasio aktifitas

Rasio aktifitas adalah rasio yang digunakan untuk mengukur dan mengambarkan bagaimana pemerintah daerah memprioritaskan alokasi dananya pada belanja rutin dan belanja pembangunan secara optimal. 


\section{Penutup}

Kesimpulan penelitian ini adalah: (a) Berdasarkan hasil perhitungan untuk rasio efektifitas dan efisiensi Pendapatan Asli Daerah Kota Palopo, kinerja keuangan Pemerintah Kota Palopo dalam merealisasikan PAD yang direncanakan dibandingkan dengan Anggaran yang ditetapkan belum efektif karena rasio efektifnya belum mencapai 1 (satu) atau 100 persen, (b) Didalam pengukuran terhadap rasio aktivitas menggambarkan bahwa presentase dana yang digunakan untuk belanja rutin lebih besar dibanding belanja investasi (belanja pembangunan) dimana hal ini berarti pula bahwa pemerintah Kota Palopo masih memprioritaskan alokasi dananya pada belanja rutin dan belanja pembangunan secara optimal. Adapun saran dari penelitian ini adalah: (a) Pemerintah kota palopo hendaknya mengupayakan agar para investor tertarik untuk menanamkan modal dan melakukan investasi di kota palopo sehingga dapat menambah value pada Pendapatan Asli Daerah (PAD) serta mengoptimalkan pemungutan pendapatan retribusi daerah yang merupakan komponen utama dalam menentukan nilai Pendapatan Asli Daerah (PAD) agar lebih ditingkatkan sehingga menunjukkan trend yang positif terhadap rasio efektifitas. (b) Kinerja keuangan dalam hal rasio efisiensi yang sudah menunjukkan trend yang positif agar dipertahankan atau lebih ditingkatkan lagi.

\section{Daftar Pustaka}

Govermment Accounting Standard Board (GASB), dalam Koncept

Statements No.2, 1994;

Halim, Abdul. 2004. Akuntansi Sektor Publik: Akuntansi Keuangan Daerah, Salemba Empat. Jakarta.

Indra Bastian, 2001 Public Sektor Accounting, $4^{\text {th }}$ Edition, Pitman Publishing, London;

Langefender (1993) dalam Glynn, J.J (1993), Public Sektor Financial Control and Accounting, $2^{\text {nd }}$ Ed. Oxford: Blackwell;

Mardiasmo, (2002), Akuntansi Sektor Publik;

Muhammad Gade, 2006. Financial Accounting, McGraw Hill International, New York;

Musgrave, Richard A dan B. Musgrave, Peggy Public Finance in Theory And Practice (Hadiprojo, Ekonomi Publik)

Peraturan Pemerintah Nomor 24 Tahun 2005 tentang Standard Akuntansi Pemerintahan; 